\title{
Metabolic Studies in Diabetics on Tolbutamide. Comparison of a Single Dose with a Divided Dose Regimen
}

\author{
A.I. VinIK, W.P.U. JACKson, P. KeLLIER and N. Marine
}

Endocrine Research Group of the Council for Scientific and Industrial Research in the Department of Medicine, University of Cape Town and Groote Schuur Hospital, Cape, South Africa

\section{Received: December 18, 1967}

Summary. This study compares blood glucose, plasma insulin and tolbutamide values throughout $48 \mathrm{~h}$ in 10 subjects on a single daily dose of tolbutamide and on a divided dose regimen (the two regimens are equally effective in their blood sugar lowering effect at all times throughout the 48 hours). - A plasma tolbutamide of $2-5 \mathrm{mg}$ per cent was found to have some blood sugar lowering effect, and $24 \mathrm{~h}$ after a single oral dose effective levels were detectable in the plasma of some subjects. Plasma insulin appears to respond to fluctuating glucose levels rather than to the tolbutamide levels and cannot fully account for the prolonged action of tolbutamide. Tolbutamide given intravenously $3 \mathrm{~h}$ after a previous oral dose elicited a further rise in plasma insulin. The response was enhanced when the interval was increased to $18 \mathrm{~h}$. A second peak in plasma insulin levels was often seen one hour after intravenous tolbutamide. - No insulin response was seen to repeated oral doses given at six to eight hour intervals. - An unexpected rise in plasma FFA was frequently observed ten minutes after intravenous tolbutamide. This may be attributed to the high circulating levels of tolbutamide which are measured as FFA by the method employed. - The mechanism of prolonged tolbutamide action remains unclear. These findings and their possible relationship to this action are discussed.

Etudes métaboliques chez des diabétiques traités par le tolbutamide. Comparaison entre les effets d'wne seule dose et ceux de doses fractionnées

Résumé. Cette étude compare les valeurs de la glycémie, de l'insuline plasmatique et du tolbutamide pendant $48 \mathrm{~h}$ consécutives chez dix sujets, les uns recevant une seule dose de tolbutamide par jour, les autres recevant des doses fractionnées (les deux types d'administration sont 8 oalement efficaces quant à leur effet d'abaisser la glycémie pendant toute la durée des $48 \mathrm{~h}$ ). - On a constaté que 2 à $5 \mathrm{mg}$ pour cent de tolbutamide dans le plasma provoquaient une certaine diminution de la glycémie, et $24 \mathrm{~h}$ après une seule dose administrée oralement, on a trouvé des taux efficaces dans le plasma de certains sujets. - L'insuline plasmatique semble réagir à la fluctuation des taux de glucose plutôt qu'aux taux de tolbutamide et ne peut pas expliquer entièrement l'effet prolongé du tolbutamide. - Le tolbutamide administré par voie intraveineuse trois heures après une dose précédemment prise par voie orale provoqua une augmentation supplémentaire de l'insuline plasmatique. Cet effet était accentué lorsque l'intervalle était porté à $18 \mathrm{~h}$. On a souvent observé un second pic dans les taux d'insuline plasmatique une heure après une injection intraveineuse de tolbutamide. - Aucune réponse insulinique n'a été constatée après des doses orales répétées, administrées à des intervalles de 6 à $8 \mathrm{~h}$. - On a souvent observé une augmentation inattendue des FFA du plasma dix minutes après une injection intraveineuse de tolbutamide. Ceci peut être attribué aux taux très élevés de tolbutamide circulant qui sont mesurés comme FFA par la méthode employée. - Le mécanisme de l'action prolongée du tolbutamide demeure obscur. Ces constations et leurs relations possibles avec cette action font l'objet de discussions.

Stoffwechseluntersuchungen bei mit Tolbutamid behandelten Diabetikern. Vergleich einer einmaligen Gabe mit der Verabreichung in verteilten Dosen

Zusammenfassung. Die vorliegende Arbeit vergleicht das Verhalten von Blutzucker, Seruminsulin und Tolbut. amidspiegeln im Plasma bei 10 Personen während 48 Std nach Verabreichung von Tolbutamid in einer Einzelgabe oder in verteilten Dosen. (Beide Arten der Verabreichung hatten während $48 \mathrm{Std}$ den gleichen blutzuckersenkenden Effekt.) Schon 2 bis $5 \mathrm{mg} \%$ Tolbutamid im Plasma führ. ten zu einer Blutzuckersenkung und bei einigen Probanden waren 24 Std nach einmaliger Tolbutamidgabe noch wirksame Konzentrationen im Plasma nachweisbar. Das Seruminsulin scheint eher auf die Schwankungen des Blutzuckers als auf die Tolbutamidkonzentration anzusprechen und kann nicht in vollem Umfang für die verlängerte Wirkungsdauer des Tolbutamids verantwortlich gemacht werden. - Intravenöse Tolbutamidzufuhr 3 Std nach einer oralen Gabe führte zu einem weiteren Anstieg des Seruminsulins. Durch Verlängerung des Abstandes auf 18 Std wurde dieser Effekt verstärkt. Eine Stunde nach i. v. Tolbutamidgabe wurde häufig ein erneutes Ansteigen der Seruminsulinspiegel festgestellt. - Wiederholte orale Gaben in 6-8 stündlichen Abständen bewirkten keine Änderung der Seruminsulin-Konzentrationen. Ein unerwarteter Anstieg der freien Fettsäuren im Plasma war ständig $10 \mathrm{~min}$ nach i.v. Tolbutamidgabe festgestellt worden. Dieser Anstieg ist durch die hohen TolbutamidSpiegel bedingt, die bei der Bestimmungsmethode der FFS miterfaßt werden. Die Wirkungsweise der verzögerten Tolbutamidreaktion bleibt noch ungeklärt. Die Ergebnisse und ihre Beziehungen zu dem verzögerten Tolbutamid-Effekt werden diskutiert.

Key-words: Tolbutamide, free fatty acids (FFA), insulin (IRI), glucose, single dose, divided dose, maturity onset diabetics, oral, intravenous.
Tolbutamide taken orally has a half-life of $3-8 \mathrm{~h}$ [3]. Its major action is to stimulate the release of insulin $[21,22,29,26]$, which itself has a half-life of about $20-30 \mathrm{~min}[5,12]$. Reports of prolonged hypoglycaemia after single small doses of tolbutamide $[24,2,37$,
$19,28,9,13,7]$. suggest either an effect apart from the stimulation of insulin release or a delay in tolbut. amide catabolism and excretion.

In a previous report [35] we showed that in 89 per cent of tolbutamide-responsive maturity-onset diabe- 
tics there was no difference in control whether the daily dose of tolbutamide was given all at one time or in divided doses throughout the day. We have obtained $48 \mathrm{~h}$ profiles of plasma glucose, insulin (IRI), free fatty acid (FFA) and tolbutamide levels in some of these weight, Documenta Geigy Tables), 5 were overweight but not obese. Duration of diabetes ranged from four months to fourteen years.

Every subject had been assessed as an outpatient on each dose-schedule for three months. During the

Table 1. The actual plasma values for glucose, insulin and tolbutamide are shown for the various times during the single dose $(S)$ and divided dose $(D)$ regimens

\begin{tabular}{|c|c|c|c|c|c|c|c|c|c|c|c|c|c|c|c|c|}
\hline \multicolumn{17}{|c|}{48 h Plasma Values } \\
\hline \multicolumn{17}{|c|}{ Glucose $\mathrm{mg} / 100 \mathrm{ml}$} \\
\hline & \multicolumn{2}{|c|}{ 8A.M. } & \multicolumn{2}{|c|}{ 12M.D. } & \multicolumn{2}{|c|}{ 6P.M. } & \multicolumn{2}{|c|}{$12 \mathrm{MN}$} & \multicolumn{2}{|c|}{ 8A.M. } & \multicolumn{2}{|c|}{ 12M.D. } & \multicolumn{2}{|c|}{ 6P.M. } & \multicolumn{2}{|c|}{$12 \mathrm{MN}$} \\
\hline & $\overline{\mathrm{S}}$ & $\overline{\mathrm{D}}$ & $\overline{\mathrm{S}}$ & $\overline{\mathrm{D}}$ & $\overline{\mathrm{S}}$ & $\mathrm{D}$ & $\overline{\mathrm{S}}$ & $\overline{\mathrm{D}}$ & $\mathrm{S}$ & $\bar{D}$ & $\overline{\mathrm{S}}$ & $\overline{\mathrm{D}}$ & $\overline{\mathrm{S}}$ & $\overline{\mathbf{D}}$ & $\overline{\mathrm{S}}$ & $\mathrm{D}$ \\
\hline D.S. & 115 & 177 & 186 & 245 & 108 & 247 & 131 & 197 & 110 & 197 & 90 & 202 & 84 & - & 104 & 222 \\
\hline H.G. & 139 & 134 & 150 & 134 & 211 & 143 & 150 & 157 & 211 & 139 & 125 & 159 & 115 & 139 & - & 119 \\
\hline E.O. & 222 & 143 & 148 & 191 & 150 & 208 & 177 & 195 & 193 & 177 & 124 & 106 & 197 & 119 & 208 & 146 \\
\hline G.N. & 139 & 124 & 148 & 179 & 111 & 124 & 120 & 161 & 102 & 115 & 86 & 88 & 141 & 115 & 141 & 124 \\
\hline J.A. & 99 & 131 & 95 & 117 & 101 & - & 70 & 154 & 106 & 141 & 197 & 159 & 92 & - & 120 & 150 \\
\hline A.L. & 127 & 154 & 115 & 197 & 106 & 195 & 195 & 134 & 138 & 155 & 177 & 182 & 166 & 173 & 209 & 146 \\
\hline F.S. & 65 & 86 & 70 & 97 & 79 & 88 & - & - & 72 & 88 & 90 & 119 & 79 & 102 & 95 & 86 \\
\hline G.A. & 134 & 139 & 159 & 117 & 117 & 134 & 138 & 157 & 161 & 143 & 166 & 166 & 77 & - & 131 & 125 \\
\hline E.W. & - & 145 & - & 209 & 138 & 134 & 186 & - & 188 & 141 & 217 & 270 & 95 & 150 & 124 & - \\
\hline A.P. & 336 & 163 & 306 & 222 & 188 & 136 & 230 & 208 & 193 & 132 & 193 & 186 & 133 & 132 & 217 & 208 \\
\hline mean & 153 & 139.6 & 155 & 175 & 131 & 156.5 & 155 & 170.4 & 147 & 142.8 & 147 & 163.7 & 118 & 132.9 & 150 & 147.3 \\
\hline
\end{tabular}

S. - Single Dose

D. -Divided Dose

Insulin Units $/ \mathrm{ml}$

\begin{tabular}{|c|c|c|c|c|c|c|c|c|c|c|c|c|c|c|c|c|}
\hline D.S. & 59 & 27 & 150 & 55 & - & 101 & 78 & 46 & 57 & 31 & 43 & 75 & - & 188 & - & 78 \\
\hline H.G. & 26 & 141 & 46 & 250 & 125 & 250 & - & 146 & 58 & 153 & 40 & 250 & 78 & 250 & 66 & 250 \\
\hline E.O. & 29 & 39 & 135 & 70 & 135 & 130 & 71 & 48 & 28 & 44 & 92 & 48 & 198 & 125 & - & 79 \\
\hline $\mathrm{N}$ & 38 & 23 & 46 & 117 & 58 & 87 & 48 & 46 & 49 & 34 & $5 \overline{5}$ & 69 & 77 & 53 & 68 & 27 \\
\hline J.A. & 167 & 19 & 175 & 18 & 150 & - & 215 & 35 & 120 & - & 167 & - & 175 & - & 175 & 69 \\
\hline A.L. & 37 & 16 & 38 & 35 & 118 & 58 & 103 & 16 & 50 & 26 & 150 & 42 & 150 & 48 & 150 & 20 \\
\hline F.S. & 14 & 11 & 39 & 13 & 27 & 24 & - & 14 & 14 & 16 & 4 & 14 & 21 & 15 & 23 & - \\
\hline G.A. & 32 & - & 53 & - & 29 & 22 & 23 & 9 & 28 & 23 & 49 & 63 & 46 & 22 & 25 & 22 \\
\hline E.W. & 40 & 42 & 59 & 137 & 87 & 79 & 47 & - & 79 & 44 & 122 & 95 & 75 & 57 & 53 & - \\
\hline A.P. & 170 & 39 & 129 & 205 & 129 & 125 & 105 & 102 & 60 & 88 & 117 & 138 & 83 & 169 & 100 & $16 \overline{0}$ \\
\hline ear & 61.2 & 39.7 & 87.0 & 100.0 & 95.3 & 99 & 86. & 51. & 54.0 & 51.0 & 100. & 88. & 95. & 99.6 & 86.2 & 51. \\
\hline
\end{tabular}

Tolbutamide $\mathrm{mg} / 100 \mathrm{ml}$

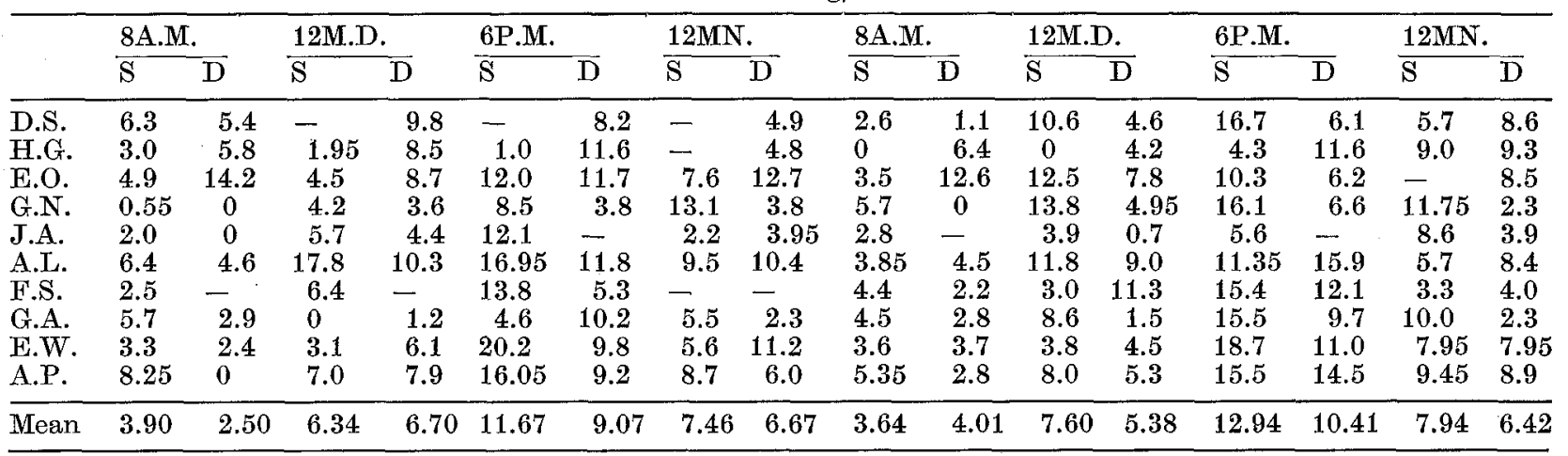

subjects on both single and divided dose schedules, in the hope that this might help to explain the complexities of tolbutamide action.

\section{Subjects}

There were 10 subjects aged 48-65 years, 6 females and 4 males. Two were obese $(15$ per cent above average course of each regimen the subjects were admitted to hospital for two 48 hour periods. All subjects were on a "diabetic diet" providing 1600 calories, $85 \mathrm{~g}$ protein, $58 \mathrm{~g}$ fat, $190 \mathrm{~g}$ carbohydrate.

Tolbutamide was administered in divided doses at 7 a.m., 12 midday and 5.30 p.m. on the one regimen, and the single dose was given at 11 a.m. each day 
on the other. The total daily amount was 1.5 grams and remained the same for both treatment schedules. On the third day after admission standard $1 \mathrm{~g}$ intravenous tolbutamide tolerance tests were performed [33].

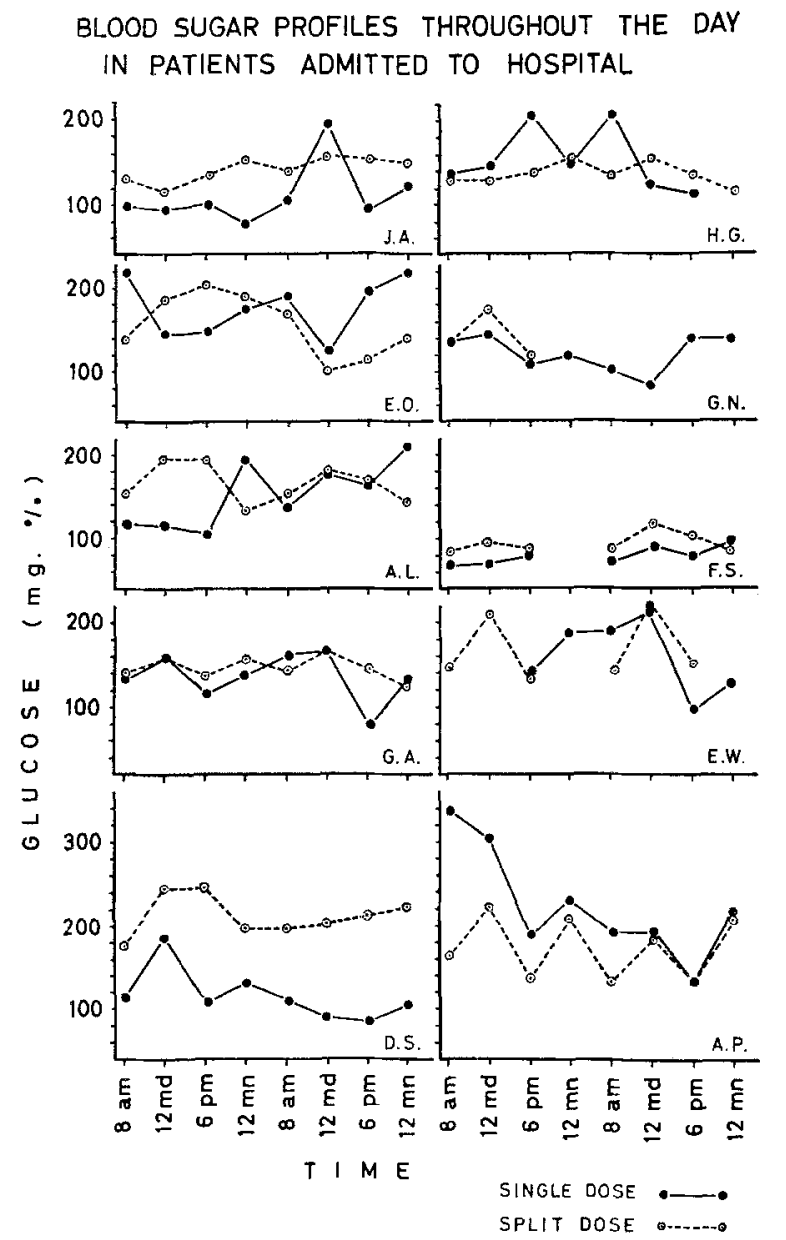

Fig. 1. Continuous lines indicate blood glucose levels with patients on the "single tolbutamide dose" scheme and interrupted lines indicate the same on divided doses

\section{Measurements}

Venous blood for insulin and tolbutamide was taken at 8 a.m., 12 midday, 6 p.m. and 12 midnight, and allowed to stand for about one hour, after which the serum was separated and stored at $-20^{\circ} \mathrm{C}$ until estimations were performed up to some months later. Venous blood for glucose was taken into fluoride/oxalate tubes and immediately refrigerated until the end of the test when all samples were estimated.

Insulin was measured by the HALES-RANDLE method [16], as modified by the Radiochemical Centre, Data Sheet 5661. Glucose was measured by the Autoanalyzer Hofrman method [18]. Tolbutamide was measured by a modified. Spingler method [30], and free fatty acid by the procedure of Trovt et al [32].

\section{Results}

1. Forty-eight hour profiles (Table 1 shows all values for the two dose-schedules)

Blood Glucose. Fig. 1 shows the blood sugar levels in the subjects on the two regimens. Fig. 2 shows their mean values. No significant difference in glucose values emerges for any of the test times. One subject, D.S., was better controlled on the single-dose schedule. With divided doses slightly higher mean glucose values were seen at 12 midday and $6 \mathrm{p} . \mathrm{m}$. The mean midnight and fasting glucose values were similar on both regimens despite differences of $6^{1} / 2 \mathrm{~h}$ in time since last dose of tolbutamide.

Plasma Tolbutamide. The blood levels of tolbutamide run approximately parallel to each other in the two regimens (Table 1 and Fig. 2). Maximum values were generally found at $6 \mathrm{p} . \mathrm{m}$. on both regimens. A level as low as $3-5 \mathrm{mg}$ per $100 \mathrm{ml}$ produced a blood

TOLBUTAMIDE TRIAL $48 \mathrm{Hr}$. MEAN PLASMA LEVELS
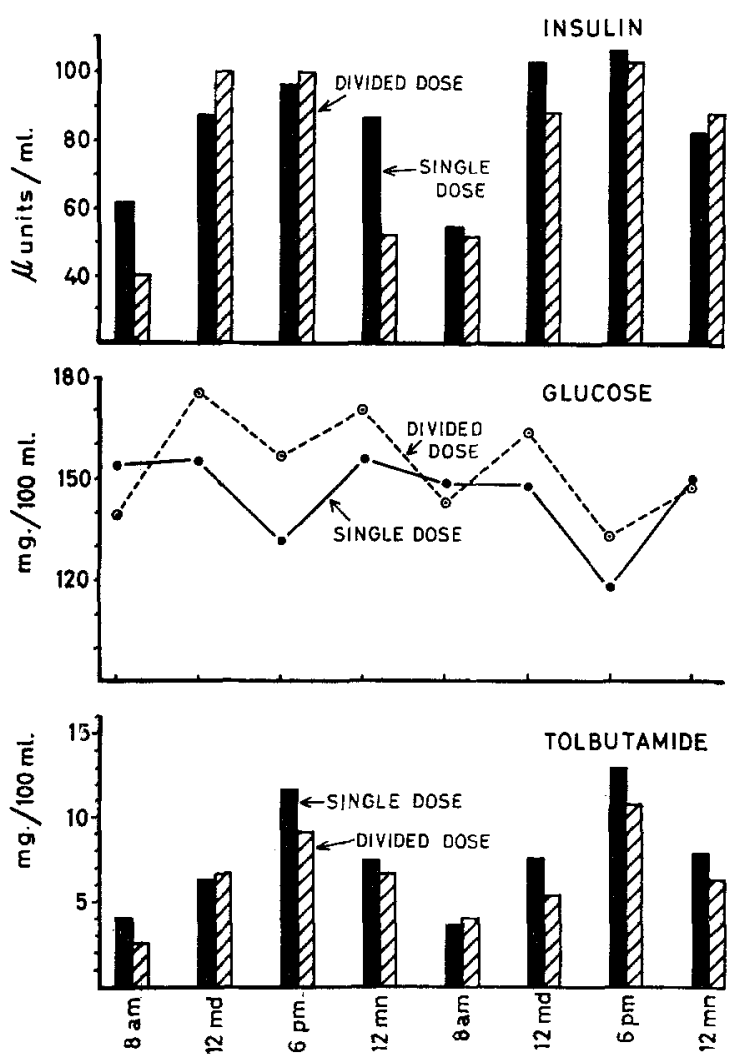

Fig. 2. Mean plasma insulin and tolbutamide levels are shown in relation to the mean glucose levels for the two regimens throughout the course of $48 \mathrm{~h}$. (18 h and $3 \mathrm{~h}$ indicate time since previous oral doses of tolbutamide)

sugar-lowering effect. This can be seen in subjects with high fasting blood glucose levels on admission and no detectable plasma tolbutamide, in whom the later fasting glucose values became normal with plasma tolbutamide levels of $3-5 \mathrm{mg}$ per cent. 
Table 2. The actual values for glucose, insulin, tolbutamide and FFA during standard intravenous tolbutamide tests performed 3 and 18 h after a previous oral dose are shown

Intravenous Tolbutamide Test

\begin{tabular}{|c|c|c|c|c|c|c|c|c|c|c|c|c|c|c|c|c|}
\hline \multicolumn{17}{|c|}{ Glucose $\mathrm{mg} / 100 \mathrm{mI}$} \\
\hline & \multicolumn{2}{|l|}{ fast } & \multicolumn{2}{|c|}{$10 \mathrm{~min}$} & \multicolumn{2}{|c|}{$20 \min$} & \multicolumn{2}{|c|}{$30 \mathrm{~min}$} & \multicolumn{2}{|c|}{$45 \mathrm{~min}$} & \multicolumn{2}{|c|}{$60 \mathrm{~min}$} & \multicolumn{2}{|c|}{$90 \mathrm{~min}$} & \multicolumn{2}{|c|}{$120 \mathrm{~min}$} \\
\hline & $18 \mathrm{~h}$ & $3 \mathrm{~h}$ & $\overline{18 \mathrm{~h}}$ & $\overrightarrow{3 \mathrm{~h}}$ & $18 \mathrm{~h}$ & $3 \mathrm{~h}$ & $18 \mathrm{~h}$ & $\overline{3 h}$ & $18 \mathrm{~h}$ & $\overline{3 h}$ & $18 \mathrm{~h}$ & $\overline{3 \mathrm{~h}}$ & $18 \mathrm{~h}$ & $\overline{3 h}$ & $18 \mathrm{~h}$ & $\overline{3 h}$ \\
\hline $\mathrm{S}$ & - & 184 & - & 182 & - & 146 & - & 145 & - & 143 & - & 131 & - & 148 & - & 150 \\
\hline H.G. & 143 & 134 & 129 & 129 & 146 & 129 & 141 & 132 & 141 & 129 & 154 & 134 & 134 & 124 & 136 & 120 \\
\hline Q. 0 & 175 & 152 & 172 & 150 & 172 & 132 & 163 & 146 & 157 & 131 & 155 & 131 & 146 & 122 & 138 & 108 \\
\hline G.N. & 164 & 88 & 168 & 75 & 155 & 72 & 177 & 72 & - & 72 & 163 & 77 & 146 & 75 & 138 & 81 \\
\hline J.A. & 113 & 119 & 102 & - & 84 & 113 & 86 & 117 & 95 & 106 & 88 & - & 86 & 99 & 86 & 101 \\
\hline A.L. & 148 & 150 & 145 & 146 & 148 & 145 & 141 & 136 & 134 & 132 & 134 & 138 & 127 & 129 & 125 & 127 \\
\hline $\mathrm{FS}$ & 83 & 141 & 70 & 124 & 70 & 90 & 61 & 70 & 56 & 65 & 48 & 70 & 57 & 74 & 65 & 79 \\
\hline G.A. & 153 & 170 & 147 & 161 & 140 & 159 & 143 & 150 & 128 & 146 & 132 & 141 & 120 & 131 & 103 & 152 \\
\hline E.W. & 190 & 148 & 181 & 136 & 181 & 127 & 164 & 122 & 161 & 113 & 159 & 102 & 148 & 99 & 148 & 99 \\
\hline A.P. & 158 & 92 & 151 & 106 & 136 & 97 & 153 & 101 & 一 & 99 & 144 & 92 & 129 & 90 & 117 & 84 \\
\hline & 147 & 138 & 141 & 134 & 137 & 121 & 137 & 119 & 125 & 114 & 131 & 113 & 121 & 109 & 117 & $\overline{110}$ \\
\hline
\end{tabular}

Insulin Units/ml

\begin{tabular}{|c|c|c|c|c|c|c|c|c|c|c|c|c|c|c|c|c|}
\hline D.S. & - & 42 & - & 67 & - & 54 & - & 49 & - & 110 & - & 59 & - & 29 & - & 47 \\
\hline H.G. & 89 & 114 & 90 & 81 & 98 & - & 108 & 66 & 80 & 59 & 63 & 72 & 50 & 78 & 31 & 78 \\
\hline E.O. & 124 & 99 & 134 & 108 & 128 & 92 & 100 & 81 & 103 & 175 & 106 & 250 & 114 & 156 & 51 & 100 \\
\hline G.N. & - & 27 & - & 49 & - & 37 & - & 40 & - & 29 & - & 28 & - & 30 & - & 25 \\
\hline J.A. & 54 & 49 & 72 & 178 & 57 & 93 & 73 & 81 & 82 & 49 & 64 & 59 & 43 & 30 & 45 & 26 \\
\hline A.L. & 95 & 20 & 67 & 36 & 79 & 26 & 65 & 40 & 147 & 19 & 92 & 25 & 72 & 53 & 63 & 14 \\
\hline F.S. & 50 & 67 & 67 & 198 & 69 & 64 & 64 & 37 & 53 & 45 & 38 & 35 & 50 & 67 & 44 & 25 \\
\hline G.A. & 44 & 44 & 137 & 60 & 86 & 61 & 57 & 55 & 36 & 46 & 50 & 53 & 29 & 75 & 70 & 51 \\
\hline E.W. & 55 & 60 & 82 & 107 & 112 & 57 & 62 & 47 & 62 & 35 & 72 & 54 & 52 & 98 & 88 & 83 \\
\hline A.P. & 73 & 56 & 250 & 38 & 177 & 60 & 109 & 40 & - & 112 & 117 & 112 & 89 & 49 & 97 & 45 \\
\hline mean & 73 & 58 & 112 & 92 & 101 & 60 & 80 & 54 & 80 & 64 & 75 & 75 & 62 & 67 & 61 & 49 \\
\hline
\end{tabular}

Free fatty acid

Equivalents/ml

\begin{tabular}{|c|c|c|c|c|c|c|c|c|c|c|c|c|c|c|c|c|}
\hline & \multicolumn{2}{|l|}{ fast } & \multicolumn{2}{|c|}{$10 \mathrm{~min}$} & \multicolumn{2}{|c|}{$20 \mathrm{~min}$} & \multicolumn{2}{|c|}{$30 \mathrm{~min}$} & \multicolumn{2}{|c|}{$45 \mathrm{~min}$} & \multicolumn{2}{|c|}{$60 \mathrm{~min}$} & \multicolumn{2}{|c|}{$90 \min$} & \multicolumn{2}{|c|}{$120 \mathrm{~min}$} \\
\hline & $18 \mathrm{~h}$ & $3 \bar{h}$ & $18 \mathrm{~h}$ & $3 \mathrm{~h}$ & $18 \mathrm{~h}$ & $\overline{3 h}$ & $18 \mathrm{~h}$ & $3 \bar{h}$ & $18 \mathrm{~h}$ & $3 \mathrm{~h}$ & $\overline{18 \mathrm{~h}}$ & $\overline{3 \mathrm{~h}}$ & $18 \mathrm{~h}$ & $3 \mathrm{~h}$ & $\overline{18 \mathrm{~h}}$ & $3 \mathrm{~h}$ \\
\hline $\mathrm{S}$ & - & 982 & - & 630 & - & 68 & - & 717 & - & 630 & - & 542 & - & 630 & - & 682 \\
\hline . & 1172 & 92 & 1083 & 73 & 996 & 7 & 699 & 18 & 857 & 787 & 962 & 804 & 1048 & & 1154 & 1014 \\
\hline .0 . & 1207 & 76 & 857 & 87 & 577 & 33 & 839 & 332 & 945 & 437 & 1048 & 559 & 1154 & 6 & 11 & 752 \\
\hline .1 & 647 & 26 & 647 & 36 & 594 & 48 & 507 & 48 & - & 542 & 699 & 6 & & 13 & & 1364 \\
\hline A & 1154 & 677 & 1626 & 81 & 1381 & 75 & 1154 & 7 & 768 & 771 & 927 & y & 962 & 8 & 11 & 1055 \\
\hline .1 & 787 & 610 & 908 & 857 & 734 & 71 & 734 & 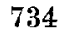 & 908 & 927 & 1083 & 5 & 1083 & 10 & 1172 & 1014 \\
\hline S & 489 & 1055 & 1469 & 1039 & 822 & 771 & 559 & 614 & 454 & 567 & 419 & 5 & 610 & 7 & 1469 & 1275 \\
\hline & 8 & 1039 & 7 & 103 & 1312 & 10 & 71 & & 577 & 598 & 55 & & 64 & & 839 & 504 \\
\hline E.V & 1083 & 804 & 1067 & 752 & 874 & 64 & 996 & 908 & 927 & 908 & 577 & 577 & 839 & 891 & - & 1031 \\
\hline A.P. & 630 & 507 & 996 & 908 & 857 & 454 & 1207 & 525 & - & 664 & 822 & 734 & 1067 & 610 & 857 & 927 \\
\hline & 890 & 100 & 1033 & 802 & 905 & 000 & 824 & 662 & 777 & 683 & 825 & 721 & 889 & 828 & 1049 & 962 \\
\hline
\end{tabular}

Tolbutamide $\mathrm{mg} / 100 \mathrm{ml}$

\begin{tabular}{|c|c|c|c|c|c|c|c|c|c|c|c|c|c|c|c|c|}
\hline D.S. & - & $8 . \overline{0}$ & - & 21.0 & - & 22.5 & - & 23.4 & - & 18.6 & - & 17.7 & - & 21.7 & - & 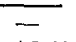 \\
\hline H.G. & - & 2.9 & - & 35 & - & - & - & 24.0 & - & 18.6 & - & 17.8 & $\ldots$ & 17.5 & - & 19.7 \\
\hline E.O. & 6.9 & 4.2 & 27.5 & 27.0 & 23.1 & 25 & 21.2 & 23.5 & 21.4 & 24.4 & 20.8 & 20.5 & 20.4 & 18.3 & 18.5 & 20.0 \\
\hline G.N. & - & - & - & - & - & - & - & - & - & - & - & - & - & - & - & - \\
\hline J.A. & - & 1.1 & - & 21.6 & - & 20.8 & - & 17.7 & - & 17.5 & - & 16.4 & - & 15.3 & - & 12. \\
\hline A.L. & 3.4 & 8.3 & 35 & 26.4 & 23.2 & 29.3 & 20.8 & 25.3 & 18.4 & 23.2 & 18.3 & 22.8 & - & 21.5 & - & 21 \\
\hline F.S. & 0.6 & 4.4 & 24.2 & 28.6 & 24.8 & 25.4 & 25 & 23.7 & 21.9 & 24.4 & 19 & 19.9 & 18.3 & 19 & 14.9 & 18 \\
\hline G.A. & 1.6 & 3.2 & 25.9 & 28.9 & 21.8 & 24.0 & 20.8 & 24.3 & 19.0 & 25.7 & 16.2 & 19.7 & 15.6 & 23.2 & 17.5 & \\
\hline E.W. & - & 1.9 & - & 21.0 & - & 17.8 & - & 16.3 & - & 17.3 & - & 15.4 & - & 14.8 & - & 15. \\
\hline A.P. & 1.3 & 9.2 & 23.0 & 35 & 19.4 & 27.9 & 19.0 & 26.4 & - & 23.3 & 18.8 & 23.7 & 13 & 20.8 & 12.6 & 19.8 \\
\hline mean & 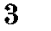 & 4.6 & 27.2 & 27.3 & 2.4 & 25.4 & 21.6 & 22.7 & 20.0 & 21.4 & 18.8 & 19.4 & 16.7 & 19.2 & 16.2 & 8 \\
\hline
\end{tabular}


We found no direct relationship between the plasma tolbutamide level and its blood sugar lowering effect, except at 6 p.m., when the highest mean tolbutamide values corresponded with the lowest blood glucose levels. Tolbutamide levels were not enhanced by the repeated oral doses of tolbutamide given on the divided dose regimen. Even up to $24 \mathrm{~h}$ after a single oral dose, tolbutamide was detectable in the plasma of some subjects.

Plasma Insulin. There was no significant difference in the plasma IRI on the two regimens.

There was a rise in IRI levels after the first daily dose of tolbutamide, and maximum plasma IRI and tolbutamide levels corresponded with the lowest glucose levels. At other times the IRI values bore no relationship to the plasma tolbutamide levels. They appeared to be more dependent on the fluctuations of plasma glucose, i.e. the higher the glucose level the greater the insulin level irrespective of the tolbutamide value.
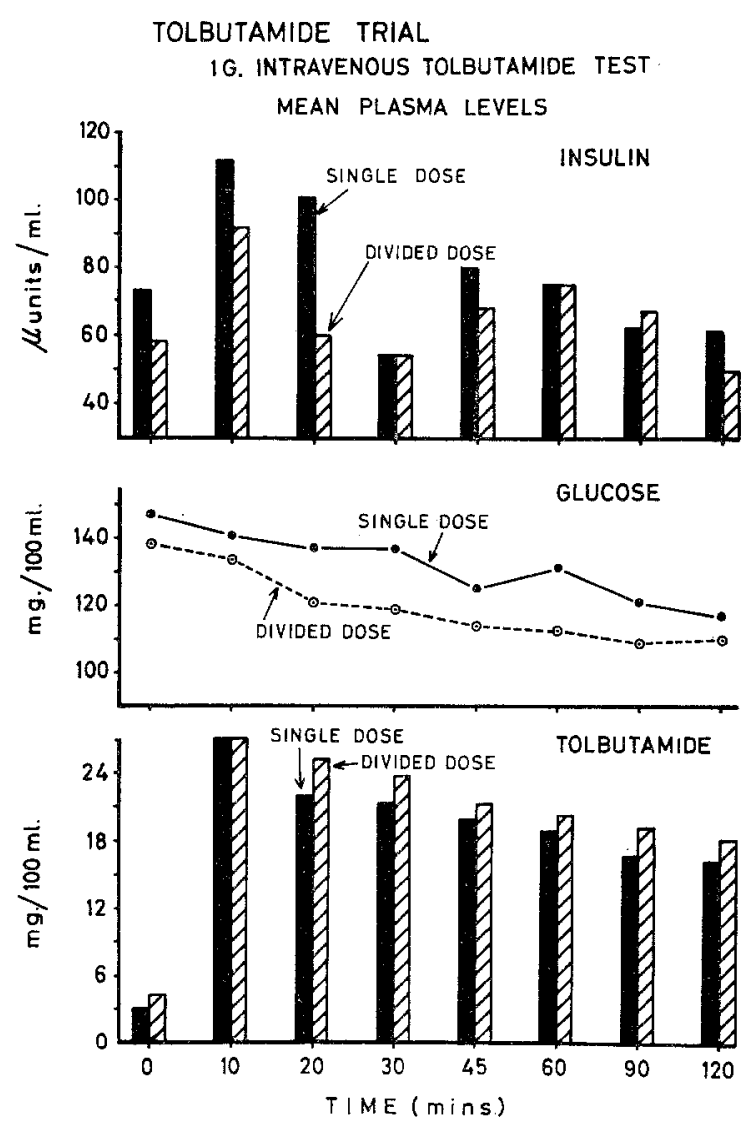

Fig. 3. Mean plasma insulin and tolbutamide values in relation to the plasma glucose response to intravenous tolbutamide $18 \mathrm{~h}$ (single dose) and $3 \mathrm{~h}$ (divided dose) after a previous oral dose

\section{Intravenous Tolbutamide Test (Table 2)}

Fig. 3 shows the mean values for all subjects during the two dose-schedules. Peak tolbutamide values in each were the same whether tolbutamide was given three hours (divided dose) or $18 \mathrm{~h}$ (single dose) after a previous oral dose (Fig. 3).

TOLBUTAMIDE TRIAL NEFA LEVEL DURING STD. I.V.T.T.

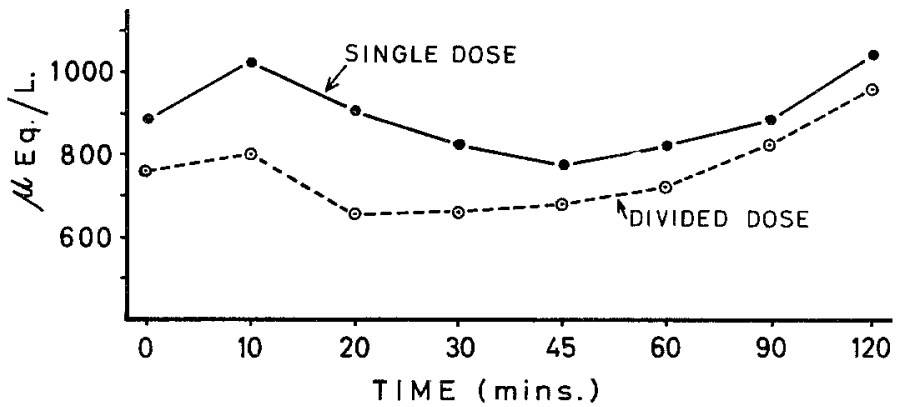

Fig. 4. Mean FFA levels after intravenous tolbutamide

The half-life of plasma tolbutamide after intravenous injection was measured from the straight portion of the curve when the plasma levels were plotted against time on a logarithmic scale. When intravenous tolbutamide was given $18 \mathrm{~h}$ after the last oral dose the mean half-life time was found to be $100 \mathrm{~min}$; when given three hours after the oral dose it was $150 \mathrm{~min}$.

Intravenously administered tolbutamide produced a further rise in plasma IRI when given either three or $18 \mathrm{~h}$ after oral tolbutamide. When tolbutamide was given intravenously $18 \mathrm{~h}$ after the oral dose the rise in IRI was significantly greater than that after three hours (Fig. 3). This contrasts with the lack of response seen with repeated oral doses, but the plasma tolbutamide level reached after intravenous administration was far greater than that attained with oral tolbutamide.

The mean plasma glucose levels were not significantly different in the two sets of tests, despite the higher insulin values attained when intravenous tolbutamide was given $18 \mathrm{~h}$ after the last oral dose (Fig. 3).

In seven subjects a rebound rise in plasma insulin was observed one hour after the intravenous administration of tolbutamide. This was associated with a fall in plasma glucose (Table 2).

An unexpected rise in the (mean) levels of plasma FFA was observed ten minutes after intravenous tolbutamide, followed by the expected fall (Fig. 4).

\section{Discussion}

CrowLey [8] compared the control of diabetes attained by single and divided doses of tolbutamide in two different groups of subjects with the control off treatment, and obtained results similar to ours.

It is not clear how tolbutamide, a substance with its short half-life, produces prolonged effects. MIRsky [25] postulated two phases of tolbutamide action, an early insulin-dependent phase and a late phase thought 
to be due to decreased insulinase activity and prolongation of insulin action. However Vouk [6] has shown that tolbutamide does not prolong the ${ }^{131}$ I-insulin half-life. Our studies do not support a prolonged insulin survival as the mechanism of the prolonged hypoglycaemic action of tolbutamide, since low blood glucose values obtain when insulin levels are also low.

Prolonged action of tolbutamide may occur in elderly subjects [9, 13], renal failure [2] or, rarely in subjects with an inability to destroy tolbutamide [3]. None of these apply to our cases, because tolbutamide (intravenously administered) was shown to disappear from the blood stream with a half-life of 100-150 min.

It has been asserted that tolbutamide may potentiate the action of insulin [20], but this was only apparent with large doses.

Differences in the action of tolbutamide and insulin $[8,17,11]$ have been disputed $[31]$, and the suggestion that tolbutamide direcly inhibits hepatic release of glucose $[21,22,10,1]$ may be accounted for by differences in measureable portal and systemic insulin levels $[26,36]$. Certainly no increase of peripheral glucose utilization occurs with tolbutamide in the absence of insulin [4].

There is a natural fluctuation in blood sugar in diabetics [14], which tolbutamide appears, from our data, to set at a lower mean level. Our finding that plasma insulin levels vary with the blood glucose rather than with tolbutamide is in keeping with that of YALOW and BERSON [36], who suggest that the sustained insulin response to tolbutamide is partly dependent on the raised glucose levels rather than the tolbutamide per se.

It has been suggested [27] that large doses of tolbutamide stimulate the pancreas to release all preformed insulin and that it is then refractory for about four hours in normal subjects and up to $24 \mathrm{~h}$ in diabetics. Our present investigations show that certainly within three hours of standard oral doses a further insulinotropic response can be obtained with intravenous tolbutamide in maturity-onset diabetics, but not with a further oral dose. An oral dose of $500 \mathrm{mg}$ thus appears to produce a relative refractoriness for several hours, which can be overcome if the blood level of tolbutamide is raised to sufficient height as by intravenous administration.

Of interest are the rebound or secondary peaks in plasma insulin levels seen at one hour after intravenous injection (Table 2) of tolbutamide, associated with a fall in blood sugar. Possibly the pancreas is refractory for only one hour, and in the face of adequate tolbutamide levels, is restimulated. Alternatively a negative feedback system may exist in which circulating insulin inhibits the pancreas, and on falling to a threshold level in the presence of circulating tolbutamide the pancreas is restimulated.

If glucose can decrease synalbumin antagonism to insulin [34] it is possible that tolbutamide may act similarly.
Finally we found an unexpected early rise in FFA after intravenous tolbutamide (observed also in MATNGAY's report [23] but not commented upon).

Tolbutamide when added to plasma in vitro in a concentration of $30 \mathrm{mg} \%$ raised the FFA measurement from $900 \mu \mathrm{Eq} /$ Litre to $1000 \mu \mathrm{Eq} /$ Litre and from $750 \mu \mathrm{Eq} /$ Litre to $890 \mu \mathrm{Eq} /$ Litre on estimations done in triplicate. We feel however that this may be only part of the explanation for the early rise in plasma FFA, and have engaged in further exploratory studies.

We can conclude that single doses of tolbutamide usually afford control as good as divided doses. This may be related to the maintenance of effective blood levels of tolbutamide for 24 hours, despite the short half-life of plasma tolbutamide. Tolbutamide does not appear to produce its prolonged hypoglycaemic effect by increasing the plasma insulin levels after the first few hours; in fact the mechanism of this phenomenon remains obscure.

Acknowledgements. This report forms part of the work of the joint University of Cape Town/C.S.I.R. Endocrine Research Group. We acknowledge with thanks financial support from Messrs. Hoechst Pharmaceuticals (Pty) Ltd., through the good offices of Mr. F. WELLNER (Johannesburg) and Mr. A. UNGEHEUER (Frankfurt). Special thanks are due to Mr. I. O'ReIIty for establishing the method for determination of plasma tolbutamide.

\section{References}

1. Ashmore, J., Y.F. CAHILL, A.S. EARLE, and S. ZoFFER: Studies on the Disposition of Blood Glucose. A Comparison of Insulin and Orinase. Diabetes 7, $1-8(1958)$.

2. BaIRd, I.M., and D.F. Richards: Hypoglycaemic Coma During Change From Insulin to Tolbutamide. Brit. med. J. 1962 I, 1585.

3. BAIRD, J.D., and L.J.P. DUNCAT: The Interpretation of the Intravenous Glucose Tolerance Test. Clin. Sci. 16, 147. (1957).

STOWER, J.M., L.W. Constable, and R. B. HUNTER : A Clinical and Pharmacological Comparison of Chlorpropamide and other Sulphonylureas. Ann. N.Y. Acad. Sci. 74, 689-695 (1959).

4. BERsoN, S.A., and R.S. YALOW: Some Remarks on the Mechanism of Action of the Sulfonylureas. Diabetes $6,274-277$ (1957).

5. - - A. Bauman, M.A. Rothschitd, and K. NeverIY: Insulin-I ${ }^{131}$ Metabolism in Human Subjects: Demonstration of Insulin Binding Globulin in the Circulation of Insulin Treated Subjects. J. clin. Invest. 35, $170-190(1956)$.

6. - - S. Weisenfieldos, M. G. Goldner, and B.W. VoLK: The Effect of Sulfonylureas on the Rates of Metabolic Degradation of Insulin- $\mathrm{I}^{\mathbf{1 3 1}}$ and Glucagon$-I^{131}$ in Vivo and in Vitro. Diabetes 6, 54-60 (1957).

7. Cherner, R., E. Q. Groppe, and J.J. RupP: Prolonged Tolbutamide induced Hypoglycemia. J. amer. med. Ass. 185, 883-884 (1963).

8. Crowley, N.F., F.W. WolfF, and H. Bloom: Tolbutamide in Diabetes. Some Clinical and Biochemical Studies. Brit. med. J. 2, 327, 1957.

9. Cushman, P., J.J. Dubois, and E. Dwyer: Protracted Tolbutamide Hypoglycemia. Amer. J. Med. 35, $196,1963$.

10. DANowski, T.S., and F.M. MATEeR: Comparative Hypoglycemic Effect of Chlorpropamide, Tolbutamide and Furfurylurea. Am. N.Y. Acad. Sci. 74, 971-978 (1959) 
11. EGELr, E.S., and H. ALP: Effect of Carbutamide on Hepatic Glycogenolysis Activated by Glucagon. A Study Using Hepatic-Vein Cathererisation in Nondiabetic Subjects. Lancet 1960 I, 803-804.

12. Elgee, N.J. R.H. WILliams, and N.D. LeE: Distribution and Degradation Studies with Insulin- $-\mathrm{I}^{131}$. J. clin. Invest. 33, 1252-1260 (1954).

13. Gardner, P., C.J. Goodner, and J.T. Dewhing: Severe Hypoglycemia in Elderly Patients Receiving Therapeutic Doses of Tolbutamide. J. amer. med. Ass. 186, 991-993 (1963).

14. GerRITZEN, F.M.: Cited by reference no. 15.

15. - The Duration of Action of Some Oral Hypoglycaemic Agents in Healthy Human Subjects. Acta med. scand. 181, $37-40$ (1967).

16. HALES, C.N., P.J. RandLE: Immunoassay of Insulin with Insulinantibody Precipitate. Biochem. J. 88, 137-146 (1963).

17. Hennes, A.R., J. Wajchendereg, S.S. Fajans, and J.W. ConN: Comparative Effects of Insulin and Orinase on Blood Levels of Pyruvate and Alpha-ketogluturate in Normal Subjects. Metabolism 6, 63-69 (1957).

18. HofFMaN, W.S.: A Rapid Photoelectric Method for the Determination of Glucose in Blood and Urine. $J$. biol. Chem. 120, 51-55 (1937).

19. KREEGER, N.: Tolbutamide-induced Hypoglycomia. Report of an Unusual Case. New Engl. J. Med. 266, $818-820(1962)$.

20. LINkE, A.: Ửber die Verstärkung der Wirkung von Insulin durch Tolbutamid. Dtsch. med. Wschr. 85, 2069-2073 (1960).

21. Loubatières, A.: Etude Physiologique et Pharmacodynamique de certains dérive's Sulfamidés Hypoglycémiants. Arch. int. Physiol. 54, 174 (1946).

22. - The hypoglycemic Sulfonamides: History and Development of the Problem from 1942-1955. Ann. N. Y. Acad. Sci. 71, 4-11 (1957).

23. Maingay, D., J.C. Tauber, H.A. DE RuYter, W. Schopman, R.M. Lequler, and R.J. Crodghs: Rapid Rise of Insulin Concentration in the Plasma After Intravenous Administration of Sodium Tolbutamide. Lancet, Feb. 1967, p. 361.

24. McKendry, J.B.R.: Fatal Hypoglycaemic Coma from the Use of Tolbutamide (Orinase). Canad. Med. Ass. J. 76, 572-573 (1957).

25. Mirsixy, I.A., G. Persutti, and S. Gitelson: The role of Insulinase in the Hypoglycemia Response to Sulphonylureas. Ann. N.Y. Acad. Sci. 71, 103-111 (1957).
26. Pfeiffer, E.F., M. Pfeifferer, H. Ditschuneit, and CoHANG-ST AmN: Clinical and Experimental Studies of Insulin Secretion Following Tolbutamide and Metahexamide Administration. Ann. N.Y. Acad. Sci. 82, $479-495$ (1959).

27. - R. Ditschuneit u. ZiegleR : Über die Bestimmung von Insulin im Blute am epididymalen Fettanhang der Ratte mit Hilfe markierter Glucose. Klin. Wschr. $39,415-426$ (1961).

28. Schwartz, J.F.: Tolbutamide-induced Hypoglycemia in Parkinson's Disease (A Case Report). J. amer. med. Ass. 176, 106-109 (1961).

29. Seltzer, H.: Quantitative Effects of Glucose, Sulfonylureas, Salicylate and Indole-3-Acetic Acid on the Secretion of Insulin Activity into Pancreatic Venous Blood. J. clin. Invest. 41, $289-360$ (1962).

30. SPINGLER, H.: Über eine Möglichkeit zur Colorimetrischen Bestimmung von N-(4-Methyl-Benzolsuffonyl)N-Butyl-Harnstoff in Serum. Klin. Wschr. 35 $533-535(1957)$.

31. SPURny, O.M., and G. Devins: Protracted Tolbutamide-induced Hypoglycemia. Arch. intern. Med. 115, $53-56(1965)$.

32. Trout, D.L., E.H. Estes, and S.J. FriedberG: Titration of Free Fatty Acids of Plasma. A study of Current Methods and a New Modification. J. Lipid. Res. April, 1960.

33. UNGer, R.H., and L.L. Madison: Comparison of Response to Intravenously Administered Sodium Tolbutamide in Mild Diabetic and Non-diabetic Subjects. J. clin. Invest. 37, 627-630 (1958).

34. VALLANCE-OWEN, J., and J. JervetL: Variations in Synalbumin Insulin Antagonism During GlucoseTolerance Tests. Lancet I, 12531967.

35. VINTK, A.I., W.P.U. JACKSON, and Norma SAXE: S. Afr. med. J. (In press).

36. Yalow, R.S., H. BLack, S. A. Berson, and M. VillazON: Comparison of Plasma Insulin Levels Following Administration of Tolbutamide and Glucose. Diabetes $9,356-362$ (1960).

37. Yonet, H.M., and H.S. BallaRd: Prolonged Severe Hypoglycemia Following Tolbutamide Therapy for Paralysis Agitans. N.Y. St. J. Med. 61 1939-1941 (1961).

A. I. VINIK, M.B., Ch. B., FCP. (SA)

Sub. Dept. Chemical Pathology,

Natal University Medical School,

P.O. Box 39, Congella,

Durban, South Africa 